Article

\title{
Decision Support System Determines The Quality of The House in Pringsewu District Using The WASPAS Method
}

\author{
Elisabet Yunaeti Anggraeni ${ }^{1}$, Riki Renaldo ${ }^{2}$, Tri Susilowati ${ }^{3}$ \\ ${ }^{1}$ STMIK Pringsewu, Manajemen Informatika, Lampung \\ ${ }^{2,3}$ STMIK Pringsewu, Sistem Informasi, Lampung
}

\section{SUBMISSION TRACK}

Recieved: February 03, 2021

Final Revision: February 25, 2021

Available Online: March 15, 2021

KEYWORD

Decision Support System, WASPAS

method, Quality of Flats.

CORRESPONDENCE

E-mail: elisabet.sugianto@yahoo.co.id

\section{A B S T R A C T}

The quality of the Flats is a concern of every citizen and related health offices who need healthy flats. To determine the quality of a flat is declared healthy or unhealthy, three criteria are used, including: housing components, housing facilities, and behavior. In this study, 5 samples were used to determine the quality of the flats, from the calculation results obtained 2 houses that were declared healthy and 3 houses were declared unhealthy. The WASPAS method is applied to determine the quality priority of healthy flats. In this study, researchers used several criteria including area, environment, infrastructure, location, security. The alternatives in this study are, Flat A, Flat B, Flat C, Flat D and Flat E. From these calculations, the results obtained from the analysis determine a healthy apartment using the WASPAS (Weight Aggregated Sum Product Assessment) method. The following: 1. Flat B gets a score of $6.88,2$. Flat A gets a score of 5.94, 3. Flat E gets a score of 5.1253, 4. Flat D gets a score of 4.6715. 5. Apartment $\mathrm{C}$ received a score of 4,57012 .

From the calculation results, the WASPAS method can be an input for the related health offices to follow up on the priority of healthy flats so that it is easier for people to choose healthy flats.

\section{INTRODUCTION}

The house is one of the basic human needs, besides the need for clothing and food, the house also functions as a place to live and is used to protect from climatic disturbances and other living things. The house is one of the residential buildings that must meet the criteria for comfort, safety and health in order to support its occupants so that they can work productively and can use it as a healthy and safe place to live for its residents [1]. 
To determine a healthy home, from the criteria used to the assessment, it has been stated in the technical manual for healthy home assessment published by the Ministry of Health of the Republic of Indonesia, the Directorate General of Disease Control and Environmental Health in 2007.

To determine the priority of the quality of a healthy flat, it is necessary to have a decision support system so that the process of assessing a healthy house runs efficiently and effectively, from the technical manual it can be used as a guideline for assessing a healthy home using a decision support system. One method that can be used for decision support is the WASPAS method.

From these problems, the authors feel the need to conduct research in analyzing the determination of the quality of flats using the WASPAS (Weight Aggregated Sum Product Assessment) method. In this study using several criteria including area, environment, location and infrastructure. The alternatives in this research are Flats A, Flats B, Flats C, Flats D and Flats E.

\section{METHODS}

\subsection{Data Collection}

In this study, data collection was completed by several methods including the following:

a. Observation (observation)

The observation method is a daily human activity using the five senses of the eye and is assisted by the other five senses. In this observation method the researcher does not only observe the object of study. This method is used to obtain data about the situation and conditions universally from the object of research, namely about healthy flats.

b. Interview (interview) Interview method The interview method is the process of obtaining information for research purposes by means of question and answer face to face, in using this method the researcher holds a question and answer by asking a few questions to find data about the implementation of healthy flats

c. Literature Study Method

Literature study is part of a scientific paper that contains discussions of previous research and scientific references related to the research described by previous researchers. In this research phase using the method of liberty or literature study in the form of references from previous journals. In this case the researcher searches for, studies and summarizes various kinds of literature or related journal references. [6]

\subsection{WASPAS}

In this study, researchers used the WASPAS (Weight Aggregated Sum Product Assessment) method in calculating and solving the problems contained in this study. Researchers used the WASPAS (Weight Aggregated Sum Product Assessment) method because this method is very appropriate in finding the most appropriate alternative priority options by using weighting.

The calculation process steps apply the WASPAS (Weight Aggregated Sum Product Assessment) method, namely:

Create a decision matrix

$$
\begin{aligned}
x= & {\left[\left(\mathrm{x} \_11 \llbracket \mathrm{x} \rrbracket \_(12 .) \mathrm{x} \_1 \mathrm{n} @ \mathrm{x} \_21 \llbracket \mathrm{x} \rrbracket\right.\right.} \\
& (22 .) \mathrm{x} \_2 \mathrm{n} @ . @ \mathrm{x} \_\mathrm{m} 1 \llbracket \mathrm{x} \rrbracket- \\
& \left.\left.(\mathrm{m} 2 .) \mathrm{x} \_\mathrm{mn}\right)\right] \ldots . . . . . . . . . . . . . . .(1)
\end{aligned}
$$

Normalizes the $\mathrm{x}$ matrix

Benefit Criteria

$\overline{x i} j=\mathrm{x} \_\mathrm{ij} /($ Max ix_ij)

Criteria Cost

$\overline{x i j}=\left(\operatorname{Min} \mathrm{ix} \_\mathrm{ij}\right) / \mathrm{x} \_\mathrm{ij}$

Calculate the value of $\mathrm{Qi}$

$$
\mathrm{Qi}=0.5 \sum_{\_}(\mathrm{j}=1)^{\wedge} \mathrm{n} \llbracket \mathrm{xijw}+0.5 \Pi
$$$$
(j=1)^{\wedge} n \llbracket(x i j) \rrbracket^{\wedge} w j \rrbracket
$$ 
Where :

$\mathrm{Qi}=$ Value from $\mathrm{Q}$ to $\mathrm{i}$

$\mathrm{X} \_\mathrm{ij}=$ Multiply the $\mathrm{x} \_\mathrm{ij}$ value by the weight (w)

$0.5=$ Provision

The best alternative is the alternative that has the highest Qi value.

\section{RESULT}

The alternatives and criteria used in the analytical study to determine the quality of the apartment using the WASPAS (Weight Aggregated Sum Product Assessment) method are as follows:

Table 1. Alternative Tables Alternative

\begin{tabular}{|l|l|}
\hline A1 & Flats A \\
\hline A2 & Flats B \\
\hline A3 & Flats C \\
\hline A4 & Flats D \\
\hline A5 & Flats E \\
\hline
\end{tabular}

Table 2. Criteria Table Criteria

\begin{tabular}{|l|l|}
\hline C1 & Broad \\
\hline C2 & Location \\
\hline C3 & Environmental \\
\hline C4 & Security \\
\hline C5 & Infrastructure \\
\hline
\end{tabular}

The match ratings for all alternatives to the broad criteria are as follows:

Very wide: 5, wide: 4, Enough: 3, Narrow: 2, Very narrow: 1.

The match ratings for all alternatives to the Location criteria are as follows:

Very near: 5, Near: 4, Enough: 3, Far: 2, Very far: 1.

The suitability ratings of all alternative environmental criteria are as follows:

Very healthy: 5, healthy: 4, Enough: 3, Less healthy: 2, Unhealthy: 1.

The suitability rating of all alternative security criteria is as follows:
Very Safe: 5,: Safe 4, Enough: 3, Less Safe: 2, Not Safe: 1.

The suitability rating of all alternative infrastructure criteria is as follows:

Very Good: 5, Good: 4, Fair: 3, Poor: 2, Not Good: 1.

Researchers gave preference weights for each criterion, namely $\mathrm{W}$ : [5, 2, 4, 3, 1].

There are two attributes in this study, namely benefit and cost. For $\mathrm{C} 1$ is the cost and $\mathrm{C} 2, \mathrm{C} 3, \mathrm{C} 4$, and $\mathrm{C} 5$ are the benefits.

Table 3. Alternative values for each criterion

\begin{tabular}{|c|c|c|c|c|c|c|}
\hline \multirow{2}{*}{ 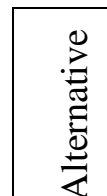 } & \multicolumn{6}{|c|}{ Kriteria } \\
\hline & C1 & C2 & C3 & & & C5 \\
\hline $\mathrm{A} 1$ & 3 & 3 & & & 3 & 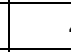 \\
\hline A2 & 4 & 4 & & & 3 & 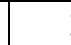 \\
\hline A3 & 2 & 2 & & & 3 & \\
\hline A4 & 3 & 2 & & & 3 & \\
\hline A5 & 5 & 2 & & & 3 & \\
\hline Max & 5 & 4 & & & 3 & \\
\hline Min & 2 & 2 & & & 3 & \\
\hline W & 4 & 2 & & 4 & 3 & \\
\hline
\end{tabular}

Calculates the normalized matrix value $\mathrm{X}$ Alternatives to the broad criteria $\mathrm{X} 11=3 / 5=0.6$

$\mathrm{X} 12=4 / 5=0.8$

$\mathrm{X} 13=2 / 5=0.4$

$\mathrm{X} 14=3 / 5=0.6$

$\mathrm{X} 15=5 / 5=1$

Alternatives to location criteria

$\mathrm{X} 21=3 / 4=0.75$

$\mathrm{X} 22=4 / 4=1$

$\mathrm{X} 23=2 / 4=0.5$

$\mathrm{X} 24=2 / 4=0.5$

$\mathrm{X} 25=2 / 4=0.5$

Alternatives to the environmental criteria

$\mathrm{X} 31=4 / 5=0.8$

$\mathrm{X} 32=5 / 5=1$

$\mathrm{X} 33=3 / 5=0.6$

$\mathrm{X} 34=2 / 5=0.4$

$\mathrm{X} 35=5 / 5=1$ 
Alternatives to security criteria

$$
\begin{aligned}
& \mathrm{X} 41=3 / 3=1 \\
& \mathrm{X} 42=3 / 3=1 \\
& \mathrm{X} 43=3 / 3=1 \\
& \mathrm{X} 44=3 / 3=1 \\
& \mathrm{X} 45=3 / 3=1
\end{aligned}
$$

\begin{tabular}{|c|c|c|c|c|c|}
\hline \multirow{2}{*}{ : } & \multicolumn{5}{|c|}{ Kriteria } \\
\hline & $\mathrm{C} 1$ & $\mathrm{C} 2$ & C3 & C4 & C5 \\
\hline A1 & 0.6 & 0.75 & 0.8 & 1 & 1 \\
\hline $\mathrm{A} 2$ & 0.8 & 1 & 1 & 1 & 0.75 \\
\hline A3 & 0.4 & 0.5 & 0.6 & 1 & 0.75 \\
\hline A4 & 0.6 & 0.5 & 0.4 & 1 & 0.75 \\
\hline A5 & 1 & 0.5 & 1 & 1 & 0.25 \\
\hline
\end{tabular}

Alternatives to infrastructure criteria

$$
\begin{aligned}
& \mathrm{X} 21=4 / 4=1 \\
& \mathrm{X} 22=3 / 4=0.75 \\
& \mathrm{X} 23=3 / 4=0.75 \\
& \mathrm{X} 24=3 / 4=0.75 \\
& \mathrm{X} 25=1 / 4=0.25
\end{aligned}
$$

Table 4. Calculation Results of the $X$ matrix Normalized

Calculate the value of all alternatives from the normalized calculation of the $\mathrm{X}$ matrix

$$
\begin{aligned}
& \mathrm{Q} 1=0.5 \sum \square(0.6 \times 5)+(0.75 \times 2)+(0.8 \times 4)+ \\
& (1 \times 3)+(1 \times 1)] \\
& =0.5 \sum \square(3)+(1.5)+(3.2)+(3)+(1) \rrbracket \\
& =0.5 \sum[(11.7) \rrbracket \\
& =0.5 \times 11.7 \\
& =5.85 \\
& =0.5 \prod \square \square(0.6) \wedge 5 \mathrm{x} \text { 『(0.75) } \unlhd \wedge 2 \mathrm{x}
\end{aligned}
$$

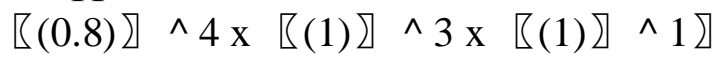

$$
\begin{aligned}
& =0.5 \prod \square(0.077 \times 0.56 \times 0.41 \times 1 \times 1 \rrbracket) \\
& =0.5 \prod \square(0.177 \rrbracket) \\
& =0.5 \times 0.177 \\
& =0.088 \\
& \mathrm{Q} 1=5.85+0.088=5.94 \\
& \mathrm{Q} 2=0.5 \sum \square(0.8 \times 5)+(1 \mathrm{x} 2)+(1 \mathrm{x} 4)+(1 \mathrm{x} 3) \\
& +(0.75 \times 1)] \\
& =0.5 \sum \llbracket(4)+(2)+(4)+(3)+(0.75) \rrbracket \\
& =0.5 \sum[(12.25) \rrbracket
\end{aligned}
$$

$$
\begin{aligned}
& =0.5 \times 13.75 \\
& =6,87 \\
& =0.5 \prod \square(0.8) \square \wedge 5 \mathrm{x} \quad \square(1) \square \wedge 2 \mathrm{x} \\
& \square(1) \rrbracket \wedge 4 \mathrm{x}[(1) \rrbracket \wedge 3 \mathrm{x}[(0.75) \square \wedge 1 \rrbracket \\
& =0.5 \prod \square(0.033 \times 1 \times 1 \times 1 \times 0.75 \rrbracket) \\
& =0.5 \prod \square(0.024 \rrbracket) \\
& =0.5 \times 0.024 \\
& =0.012 \\
& \mathrm{Q} 2=6.87+0.012=6.88 \\
& \mathrm{Q} 3=0.5 \sum \text { \ }(0.4 \times 5)+(0.5 \times 2)+(0.6 \times 4)+ \\
& (1 \times 3)+(0.75 \times 1)] \\
& =0.5 \sum \llbracket(2)+(1)+(2.4)+(3)+(0.75) \rrbracket \\
& =0.5 \sum[(9.15) \rrbracket \\
& =0.5 \times 9.15 \\
& =4,57 \\
& =0.5 \prod \square \square(0.4) \rrbracket \wedge 5 \mathrm{x} \text { 『(0.5) } \rrbracket \wedge 2 \mathrm{x} \\
& \llbracket(0.6) \rrbracket \wedge 4 \mathrm{x} \square(1) \nabla \wedge 3 \mathrm{x} \llbracket(0.75) \rrbracket \wedge 1 \rrbracket \\
& =0.5 \prod \square(0.01 \times 0.25 \times 0.13 \times 1 \times 0.75 \square) \\
& \left.=0.5 \prod \square(0.00024)\right) \\
& =0.5 \times 0.00024 \\
& =0.00012
\end{aligned}
$$

$\mathrm{Q} 3=4.57+0.00012=4.57012$

$$
\begin{aligned}
& \mathrm{Q} 4=0.5 \sum \square(0.6 \times 5)+(0.5 \times 2)+(0.4 \times 4)+ \\
& (1 \times 3)+(0.75 \times 1) \rrbracket \\
& =0.5 \sum \llbracket(3)+(1)+(1.6)+(3)+(0.75) \rrbracket \\
& =0.5 \sum[(9.35) \rrbracket \\
& =0.5 \times 9.35 \\
& =4,67 \\
& =0.5 \prod \square \square(0.6) \rrbracket \wedge 5 \mathrm{x} \square(0.5) \square \wedge 2 \mathrm{x} \\
& \llbracket(0.4) \rrbracket \wedge 4 \times \square(1) \nabla \wedge 3 \mathrm{x} \llbracket(0.75) \rrbracket \wedge 1 \rrbracket \\
& =0.5 \prod \square(0.077 \times 0.25 \times 0.026 \times 1 \times 0.75 \rrbracket) \\
& =0.5 \prod \square(0.003 \rrbracket) \\
& =0.5 \times 0.003 \\
& =0.0015
\end{aligned}
$$

$\mathrm{Q} 4=4,67+0.0015=4,6715$

$$
\begin{aligned}
& \mathrm{Q} 5=0.5 \sum \square(1 \times 5)+(0.5 \times 2)+(1 \times 4)+ \\
& (1 \times 3)+(0.25 \times 1) \square \\
& =0.5 \sum \square(2)+(1)+(4)+(3)+(0.25) \square
\end{aligned}
$$




$$
\begin{aligned}
& =0.5 \sum[(10.25) \rrbracket \\
& =0.5 \times 10.25 \\
& =5,125
\end{aligned}
$$$$
=0.5 \prod \square[(0.4) \nabla \wedge 5 \mathrm{x} \square(0.5) \nabla \wedge 2 \mathrm{x}
$$$$
\square(1) \rrbracket \wedge 4 \times \square(1) \square \wedge 3 \times \square(0.25) \square \wedge 1 \rrbracket
$$$$
=0.5 \prod \square(0.0102 \times 0.25 \times 1 \times 1 \times 0.25 \rrbracket)
$$$$
=0.5 \prod \square(0.0006 \square)
$$$$
=0.5 \times 0.0006
$$$$
=0.0003
$$

$\mathrm{Q} 5=5.125+0.0003=5.1253$

The results of calculations that have been carried out using the WASPAS (Weight Aggregated Sum Product Assessment) method are shown in the following table:

Table 5. Calculation Results of the WASPAS Method

\begin{tabular}{|c|c|c|}
\hline Alternative & Result & Rating \\
\hline A1 & 5.94 & 2 \\
\hline A2 & 6.88 & 1 \\
\hline
\end{tabular}

\begin{tabular}{|c|c|c|}
\hline A3 & 4.57012 & 5 \\
\hline A4 & 4,6715 & 4 \\
\hline A5 & 5.1253 & 3 \\
\hline
\end{tabular}

\section{CONCLUSION}

Based on the results of the analysis of the discussion and calculations using the WASPAS (Weight Aggregated Sum Product Assessment) method using the criteria of price, service, speed, security, and the number of branch offices as well as with the alternative of Flat A, Flat B, Flat C, Flat D and Flat $\mathrm{E}$ in determining the quality of a healthy apartment is as follows.

1. Flat B got a result of 6,88 with a rank of 1

2. Flats A got a result of 5.94 with a rating of 2

3. Flats E scored 5,1253 with a rank of 3

4. Flats D got 4.6715 results with a rating of 4

5. Flat C got a result of 4,57012 with a rating of 5

\section{REFERENCES}

[1] E. D. Marbun, E. R. Simanjuntak, D. Siregar, and J. Afriany, "Application of the Weighted Aggregated Sum Product Assessment Method in Determining the Best Flour for Producing Vermicelli," J. Ris. Komput., Vol. 5, no. 1, pp. 24-28, 2018.

[2] S. Barus, V. M. Sitorus, D. Napitupulu, M. Mesran, and S. Supiyandi, "Decision Support System for Teacher Appointment Continues to Apply the Weight Aggregated Sum Product Assessment (WASPAS) Method," J. Media Inform. Budidarma, vol. 2, no. 2, pp. 10-15, 2018, doi: 10.30865 / mib.v2i2.594.

[3] Ministry of Health, Republic of Indonesia, Technical Guidelines for Assessing RumahSehat, Jakarta, 2007.

[4] Suryandini Afrian, and Indriyati. 2015. "Decision Support System for Determining Student Interest in High School Using the WASPAS Method". Journal of Informatics Society. 6, 11.

[5] Efraim Turban, et al. (2005). Decision Support System and Intelligence System Ed. 7, Prentice-Hall.

[6] Olson D.L. 2004. "Comparison of Weightsin TOPSIS Models". Mathematical and Computer Modeling. 40,721-727. Freshwater Fish Seeds use the WASPAS method. Bandung: STMIK 


\section{BIOGRAPHY}

Elisabet, Graduated from the Informatics Engineering Study Program (S2) from IBI Darmajaya in 2012, currently a lecturer at STMIK Pringsewu.

Riki Renaldo, Study Program Graduated in Informatics Engineering (S2) IBI Darmajaya in 2012, Currently as a lecturer at STMIK Pringsewu.

Tri Susilowati, Graduated in the Engineering Study Program Informatics (S2) IBI Darmajaya in 2012. Currently is a Lecturer at STMIK Pringsewu 